\title{
Strategies of Causation in Gichuka
}

\author{
Nelly Karimi Mbaka ${ }^{1} \&$ Humphrey Kirimi Ireri ${ }^{1}$ \\ ${ }^{1}$ Chuka University, Kenya \\ Correspondence: Humphrey Kirimi Ireri, Chuka University, Kenya
}

Received: January 30, 2017

Accepted: June 2, 2017

Online Published: June 8, 2017

doi:10.5430/elr.v6n2p32

URL: http://dx.doi.org/10.5430/elr.v6n2p32

\begin{abstract}
This study was an investigation of the causative constructions in Gichuka, a Bantu language spoken mainly in Chuka Division in Tharaka-Nithi County of Kenya. The objective of the study was to investigate the strategies of causation in Gichuka. Review of relevant literature focused on both Bantu and non-Bantu Languages since all languages attract causation. Data was collected from a sample of ten (10) Gichuka speaking persons selected purposively and supplemented by the researcher's own intuitive knowledge of the language using introspection. Data collection was based on Self Generated Tests and semi-structured interviews, designed to elicit directed information as far as causation is concerned. Data was analyzed in phrases, clauses, sentences and tree diagrams to reveal the strategies of causation in Gichuka. Data analysis was based on the theories of Distributed Morphology (DM) and X-Bar Theory. The study found that Gichuka is a multi-strategy language as far as causation is concerned. The strategies of causation are morphological, lexical, analytic and inchoative-causative alternations. This studycontributes in analysis of the syntax of causative morpheme(s)in Gichuka. It also contributes to the body of existing knowledge on research in Bantu languages by providing data, thereby, contributing to linguistic theory, and cross-linguistic studies.
\end{abstract}

Keywords: Strategies, Causation, Gichuka

\section{Introduction}

Bantu is a family of languages that belongs to the Bantoid group. It is a Niger-Congo group of languages that descended from the mother language called the Proto-Bantu, which is believed to have been spoken 2500-3000 years ago (Guthrie, 1967). Since Proto-Bantu was spoken before the introduction of writing, it is not attested in texts, and it is believed that its words and pronunciations were reached through a reconstruction by linguists in a bid to find some logical base of its grammar. The term Bantu refers to both the people and the language. It uses such words as 'muntu' or 'mutu' for a human noun in singular and plural suffixes 'ba' or 'a' for human nouns in plural. The majority of its speakers are Swahili though most of the Swahili speakers know it as a second language (Nurse, 2003). The distribution of Bantu languages is due to a series of migrations by its speakers. In the course of these migrations, the speakers dominated the Sub-Saharan Africa, the present-day Cameroon, from where all the Bantu daughter languages originate. Further migrations led to some speakers proceeding to other areas in the African Continent spreading Bantu language wherever they settled. This is how the Bantu language bore its present-day daughters, including Kimeru, whose Gichuka dialect is our concern in this study. Kimeru is a Bantu language spoken by the Meru people living on the Eastern and Northern slopes of Mt. Kenya and on the Nyambene Hills. Its speakers settled here after migrating from the north along with other Bantus. It has nine (9) dialects with slight regional differences in accent and local words. These dialects are: Kimiutine, Igembe, Gitigania, Kiimenti, Kiitharaka, Kiigoji, Kimwimbi, Kimuthambi and Gichuka. Although these dialects are considered individual and independent languages at some point, they are fairly mutually intelligible although intelligibility lowers as the distance along the continuum increases. They share a common ancestry, for instance the migratory tradition states that the Gichuka speakers came from Mbwa along with the other Merus like Igembe and Tigania. They came through the Coast about 1300 years ago (Nurse, 2006). Their migration was provoked by the invasion from Somalia, which drove away the people living around Shungwaya.Gichuka is a Kimeru dialect spoken by the Chuka people living in Meru-South Sub-County on the South-Eastern slopes of Mt. Kenya. It is coded E541 according to Guthrie's classification of Bantu languages (Guthrie, 1971). The alphabet shows the language geographical area; for instance, (E) indicates that the language is Kenyan, the first two digits show the language group, for instance (50s) are Bantu languages while the third digit represents the dialect so, Gichuka is a Kenyan Bantu language and a dialect of Kimeru. It has approximately 97,500 speakers according to The National Population and Housing Census carried out in 2009, (The Kenya National Bureau of Statistics, 2010). 
Bantu languages are highly agglutinative and as such, they have highly productive verbal suffixes that alter the semantics and valences of verb roots (Good, 2005). The existence of these suffixes and the ways in which they combine reveal a kind of an interaction between morphology and syntax (Baker, 1988). This interactive behavior has been used to argue that indeed, morphology and syntax are related. This study delved into the causative constructions in Gichuka with a bias in the strategies of causation.

Causation is a valence increasing operation that adds a causer argument which acts upon a causee to perform an action. It is a form attached to the verb, indicating that a subject causes someone or something else to do something or cause a change in state of a non-volitional event. A causative morpheme is, therefore, that part of a word that refers to a cause relation between two events; one which is believed by the speaker to be caused by the other (Robert, 2008). Causation in Bantu languages is semantically similar to causation in many other languages. It is such that it always gives a causer subject argument to the verb among other operations. Consider the Chichewa sentence in (1) as given by Good (2003):

(1a) Mtsuko u-na-gw-a

Waterpot 3sg-pst-fall-fv

The water pot fell

Mtsikana a-na-gw-ets-a mtsuko

The girl 3sg-pst-fall-caus-fv-3waterpot

The girl made the waterpot fall

In (a) -gw- (fall) retains its semantics and valence until the suffix-ets- is suffixed to change the semantics of -gw- to causative and valence from intransitive to transitive. When causation takes place, the subject of the non-causativized form (mtsuko) is realized as an object. In (a) the action is non-agentive and non-volitional, but on causation in (b) the action needs an agent, for which reason the girl is obligatory (Good, 2003). At this early stage of this study, it is important to examine causation in Proto-Bantu in order to check for its effects on its daughters, so as to establish any adoptions or deviations.

Proto-Bantu had two causative suffixes; a short one which is a tense vowel (-i-) and a long one consisting of a short causative preceded by -ic- whose consonant (c) frequently developed into (s). The short causative is usually realized as a glide (-y-) before a vowel (Hayman, 2003). Thus;



Since Bantu languages are fairly conservative, some present day-daughter languages have maintained the whole proto-situation, -is-i-, -i-. others have divided the long causative to remain with a part of it -is-, while in contrast others have lost the long causative to remain with only the short one, -i-. Below is a table to summarize this.

Table 1. Comparison of Causatives in Proto-Bantu and some Daughter Languages

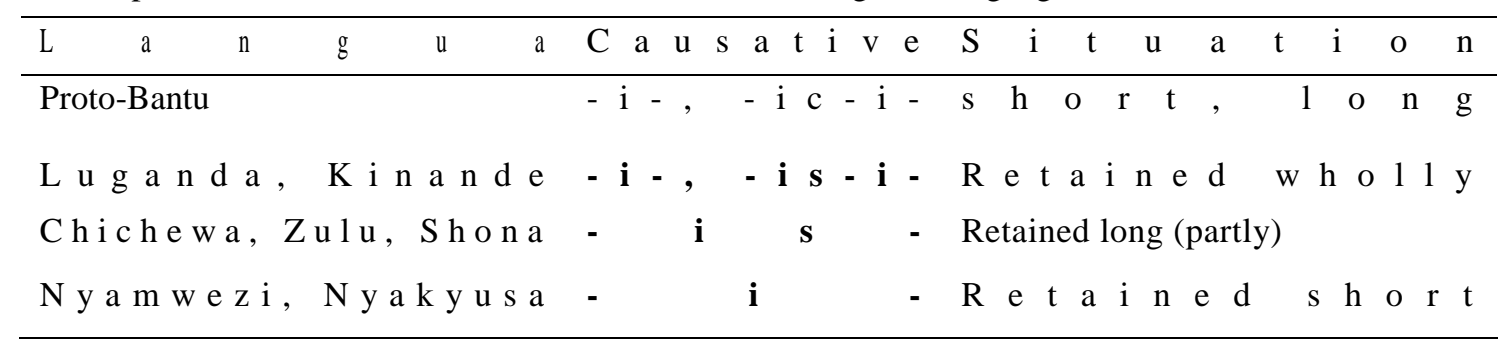

Source: Hyman (2003)

The conservative nature of Bantu languages makes it possible to develop a reconstruction of the proto-Bantu verb stem, which consists of a verb root potentially followed by a number of different categories of suffixes as shown in figure 1 below, (Hyman, 2007). 


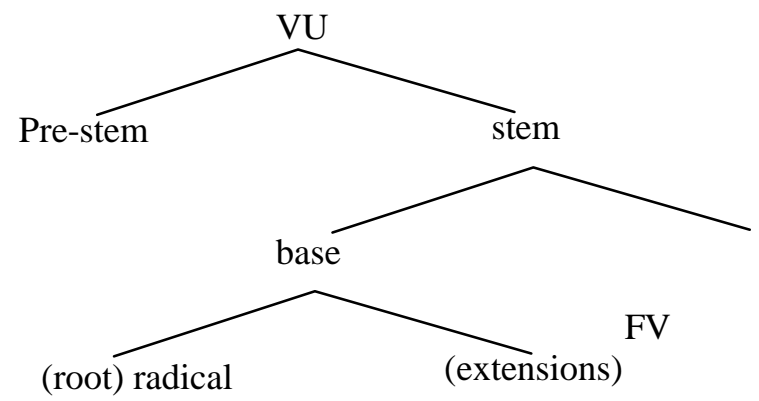

Figure 1. Proto-Bantu Verbal Unit

The verbal unit consisted of the stem as a universally accepted constituent in Proto-Bantu, which is made up of an obligatory verb root or radical, optional extensions and an obligatory inflectional final vowel (FV). The extensions are the derivational suffixes like applicative, passive, and the causative which is the subject of this study among others. Verbal extensions are characteristic of Bantu languages.

Different languages express causation differently; some use morphological, others lexical and others syntactic means or a combination. Some languages like Oromo allow chain causation, where verbs are causativized and further re-causativized by adding causative morphemes and agentive subjects (Lloret, 1987). Most Bantu languages that have been studied allow only one causative morpheme in every one verb root, hence a case of single causer single causee. This study has established that in Gichuka, this holds in that the causative morpheme $\boldsymbol{i}$ - or $-\boldsymbol{i t h}$ - cannot be attached more than once on the same verb root. When a causative morpheme is attached to an intransitive verb, the verb takes an object and therefore, the causative morpheme can be said to be a transitivizer as stated by Muriungi (2010). Further, the causative morpheme can be attached to a verbal form of a root that is not a verb. For instance it can be attached to verbal forms of adjectives (verbs of becoming) to form extended verbal forms. In this study, we establish that Gichuka is a multi-strategy language as far as causation is concerned, as it applies more than one ways in causation.

\section{Literature Review}

Available literature shows that Languages express causation in several ways.Comrie (1981) categorizes causatives into three main types; morphological, lexical and analytic. A language may use one or more ways to causativize a verb.It is assumed that Proto-Bantu, which is the Bantu mother language utilized morphologicalstrategy, with the use of two causatives; a short causative suffix -i- which is a tense vowel -i- realized as a glide $\mathbf{- y}-$ in the environment before a vowel, and a long causative suffix. The long causative was bi-morphemic, consisting the short causative -i- preceded by -ic- as

(-ic-i-). The consonant -c- in the -ic- frequently developes into an -s-

Some present-day Bantu daughter languages have retained the whole proto-situation. This is believed to be due to the conservative nature of Bantu languages. Luganda and Kinande for instance, have this characteristic. Others have divided the long causative to retain a part of it, (-ic-) like Chichewa and Shona, while others like Nyamwezi and Nyakyusa have lost the whole long causative to remain with only the short one (-i-) (Good, 2003). This is as shown below.

Luganda and Kinande-is-i- and-i- $\quad$ (maintained wholly)

Chichewa and Shona-is-

(long/partly)

Nyamwezi and Nyakyusa -i-

(short only)

Some root ending fricatives are also associated with morphological causation in Proto-Bantu since fricatives are not generally reconstructed for Proto-Bantu and this has also been retained by a daughter like Chimwini as shown below (Good, 2005).

$$
\text { pis-cause to pass }
$$

$$
\text { las -cause to divorce }
$$

In morphological causation, both the causing and the caused events are encoded in a single verbal complex via a causative morpheme and a morphologicalmarking showing the status of the affected argument. In this strategy of causation, $\mathrm{y}$ causes $\mathrm{x}$ to verb from the form $\mathrm{x}$ verbs. 
In Quechua, causation is realized by the bound morpheme -chi- attached at the end of the verb root (Robert, 2008). When this is done, a subject called causer is introduced and assigned the responsibility of the action taking place. Consider:

$$
\text { Munayhacerquererer - to want }
$$

(b) Muna-chi-y hacerquererer - to make want

It is notable that although the causer is the one responsible for the action taking place, it is the causee that performs the action and not the causer.There is an element of ordering in (b), the reason why (Robert, 2008) asserts that -chiindicates that the action of the verb is realized by another person and not the one ordering, and that it is a transitivizer, changing intransitives into transitives and transitives into di-transitives.

Causation in Quechua is expressed overtly in an agglutinative manner. This agglutinativity is the one that allows verbs to undergo the rich morphological processes that they do. Causation in Quechua is realized in transitive, intransitive and di-transitive verb roots

Kuria is a Bantu language found in Nyanza in Kenya. It does not allow for double causation and derives causation through suffixation of the bound inflectional morpheme-y-When this morpheme is added at the end of the verb root, a causer argument is inevitable (Odden, 2005). Consider the following examples;

$$
\begin{aligned}
& \text { ku- rem-a } \\
& \text {-tns-weed-fv- }
\end{aligned}
$$

to weed

$$
\begin{aligned}
& \text { ku-rem-y-a } \\
& \text {-tns-weed cause -fv- }
\end{aligned}
$$

to make weed

(6a) ko-rom-a -tns-bite-fv-

to bite

(b) ku-rum-y-a

tns-bite make-fv-

to make bite

Kiitharaka, besides being a Bantu language, is also genetically related to Gichuka, the language of concern in this study. In his study of Kiitharaka causation, Muriungi (2010) notes two causative morphemes namely transitive -iandsynthetic-ith- He also acknowledges causation under analytic -tem-a-

\section{(i) Transitive -i- causation}

\section{Consider (7):}

um-a-

$$
\text { Dry-fv }
$$

$$
\text { nguo -i-ku-um-a }
$$

Clothes sa-tns-dry-fv

the clothes have dried.

The verb -dry- (uma) in (7a) is intransitive and inchoative. The drying event in (b) has no causer and takes place spontaneously, however, when the causative -i- is suffixed to the verb, it introduces a causer argument and makes the verb take an object, hence transitivizing it. Muriungi (2010) calls it an internal causer as seen in example (8).

$$
\text { John -a-ku-um-i-a- nguo }
$$

John sa-tns-dry-ic-fv-clothes

John has dried the clothes.

The morpheme -i- has introduced a causer, John, and at the same time transitivized the verb 'uma' - dry which was initially intransitive. 


\section{(ii) - -ith- Causation}

According to Muriungi (2010) -i- is an internal causer,while-ith- is a synthetic causer which embeds a clause with a subject together with all the arguments the verb introduces. Consider example (9b):

(9a) nguo -i-ku- um -a

clothes -sa-tns- dry -fv

The clothes have dried

(b) John a-ku-um-ith-i-a Maria nguo

John sa-tns-dry-crv-ic-fv Maria clothes

John has made Maria to dry the clothes

When used this way, -ith- introduces a causer. In (9) the causer (John) is only introduced after causation in (b). -ith- is suffixed to transitives and agentive intransitives as shown in (9b). However, it cannot embed a natural cause subject such as sun and wind as illustrated in (10).

John a-ku-um-ith-i-a riuanguo

John sa-tns- dry crv-ic- sun's heat clothes

*John has made the sun's heat to dry clothes

\section{(iii) Causation under Analytic 'TEMA'}

Consider (11);

(11) Maria a-gu-tem-a- John a-um-i-a nguo.

Maria -sa-tns-make-fv-John-sa-dry-ic-fv-clothes.

Maria has made John to dry clothes.

Causatives with TEMA are bi-clausal, with the matrix clause containing the causer event and the embedded clause containing the causing event (Muriungi, 2010). The verb -TEMA- embeds a clause as its complement. Unlike the synthetic -ith-, the embedded subject can be agentive as (12) or natural cause as (13).

$$
\begin{aligned}
& \text { John a-gu-tem-a- Maria a-um-i-a- nguo } \\
& \text { John -sa-tns- make -fv- Maria -sa- dry -ic-fv- clothes } \\
& \text { John has made Maria to dry clothes } \\
& \text { John a-gu-tem-a mwathugu-um-i-a nguo } \\
& \text { John -sa-tns-tem-fv- sun's heat -tns- dry -ic-fv- clothes } \\
& \text { John has made the sun's heat to dry clothes. }
\end{aligned}
$$

So far, the discussion on the morphological strategy of causation shows that most Bantu languages have two causatives that are used independently. I show in the analysis that although Gichuka has two causatives, they can be used independently but mostly -ith- appears in the company of -i-. In this case, -ith- is used for causation and -i- for transitivity. Table 2 shows causative morphemes in some Bantu Languages. 
Table 2. Causative Morphemes in some Bantu Languages and combinations

\begin{tabular}{|c|c|c|c|}
\hline Language & Cause 1 & Cause 2 & Combination \\
\hline Basaa & -is- & - & N/A \\
\hline Bukusu & -isy- & - & N/A \\
\hline Ciyao & -is- & $-\mathrm{i}-$ & -ic-y- \\
\hline Chichewa & -its- & - & N/A \\
\hline Chimwini & -ish- & $-\mathrm{i}-$ & -ish-iz- \\
\hline Emakhuwa & -il- & - & N/A \\
\hline Ganda & -is- & $-\mathbf{i}-$ & -is-iz \\
\hline Holoholo & -isy- & $-\mathrm{i}-$ & \\
\hline Ikalanga & -is- & - & N/A \\
\hline Isangu & -is- & - & N/A \\
\hline Kiitharaka & -ith- & $-i-$ & -ith-i- \\
\hline Kinande & -is- & $-\mathrm{i}-$ & -is-i \\
\hline Kinyarwanda & -ish- & $-\mathrm{i}-$ & -ish-iz \\
\hline Kirundi & -iish- & $-\mathrm{i}-$ & \\
\hline Kitalinga & -is- & $-i-$ & -is-i- \\
\hline Kongo & -is- & - & N/A \\
\hline Korekore & -is- & - & N/A \\
\hline Lingala & -is- & - & N/A \\
\hline Lomongo & -ey- & $-\mathrm{i}-$ & \\
\hline Luvale & -is- & - & N/A \\
\hline Mwera & $-1 y-$ & - & N/A \\
\hline Ndebele & -is- & - & N/A \\
\hline Nugunu & - & $-i-$ & N/A \\
\hline Nyakyusa & - & $-\mathrm{i}-$ & N/A \\
\hline Quechua & -chi- & - & N/A \\
\hline Runyambo & -is- & $-\mathbf{i}-$ & -is-iz- \\
\hline Sesotho & -is- & - & N/A \\
\hline Shi & -is- & $-\mathrm{i}-$ & -is-iz \\
\hline Swahili & -ish-/iz & - & N/A \\
\hline Swazi & -is- & - & N/A \\
\hline Xhosa & -is- & - & N/A \\
\hline
\end{tabular}

Source: Good (2005)

As can be noted, table 2 demonstrates the Proto-Bantu situation where most of the daughter languages have two causatives; long and short. Further, as highlighted in this strategy, some have conserved the specific proto morphemes like Luganda and Kinande while some have slightly varied the long causative. Where the combination of the causatives is possible, the long causative precedes the short one further emphasizing the conservative nature of Bantu languages.

Oromo, a Cushitic language, has three types of causative morphemes referred to as cause 1, cause 2 and cause 3 as shown in table 3. 
Table 3. Oromo Causative Morphemes

\begin{tabular}{lll}
\hline Label & Form & Type \\
\hline Cause 1 & -is- & Single \\
Cause 2 & -sis- & Single/double \\
Cause3 & -eess- & De-adjectival \\
\hline \multicolumn{2}{c}{ Source: } & Lloret (1987)
\end{tabular}

-is-is suffixed to bases of intransitive verbs to transitivize them, consider:

(14a) Raff sleep (intr)

(b) Raff-is- make sleep (trans)

It can also be suffixed to causative bases for double causation, though considered a -single causative morpheme, for instance (15);

(15) dubb-is-iis- made make greet

The second causative morpheme -sis- has two Ss hence it is considered a double causative morpheme. Many transitive and some agentive intransitives permit only the suffixation of -sis- for causation. Though considered a double causative morpheme, it is used with some verbs for single causation as shown in (16) since some verbs in this language do not allow suffixation of the single causative morpheme. When used, the structure is incorrect as shown in (17).

$\begin{array}{lcc}\text { (16a) } & \text { deem } & \text { go } \\ \text { (b) } & \text { deem-sis- } & \text { make go } \\ \text { (17a) } & \text { deem } & \text { go } \\ \text { (b) } & * \text { deem-is- } & \text { make go }\end{array}$

The cause 3 -eess- is suffixed to adjectival stems to de-adjectivize them to verbs of becoming. See the examples (18b) and (19b) below;

$\begin{array}{lcc}\text { (18a) } & \text { add } & \text { white (adjective) } \\ \text { (b) } & \text { ad-eess- } & \text { whiten (trans) } \\ \text { (19a) } & \text { jab } & \text { strong (adjective) } \\ \text { (b) } & \text { jab-eess- } & \text { strengthen (trans) }\end{array}$

Unlike cause 1 and 2, cause 3 is not suffixed to stems or bases of transitive or intransitive verbs but adjectival forms only.

Oromo allows double causation. This refersto causation in which a causative morpheme is attached to an already causativized verb and an extra external causer is introduced. Consider example (20b):

(19a) Dubb -isx makes y greet $\mathrm{z}$

(b) Dubb-is- iisw makes $x$ to make $y$ greet $z$

In (20a) the causativized verb (dub-is-) is further causativized to appear as (20b). Chain causation can apply to transitive vebs as shown in (19b) or to intransitives as shown in (20b).

(20a) Gog-isx makes y to dry $z$

(b) Gog-s-iisw makes $x$ to make $y$ to dry $z$

The already causativized verbs are further causativized by attaching additional causative morphemes and extra causer agents. According to Lloret (1987), some linguists match the number of agents with the number of the -ss- in the causative morphemes. However, Lloret (1987) asserts that the number of the underlying agents does not match with the number of ss in the causative morphemes. The argument is that although double causation in Oromo is common, triple and above are also possible but rare. In a case where extensions are long, only two or three participants are expressed while the rest are omitted.Furthermore, the difference between the structures is only semantic and the two combining morphemes can do so in any order, depending on the verb and what is allowed in the language. Although chain causation is possible morphologically as illustrated in Oromo, I show in the analysis that it is not possible in Gichuka 
and what combine are analytic TUM-Aand the morphological strategies to show a causer acting on a causee who causes another causee to produce an event.

Apart from doubling and chain causation, Oromo has causer-less causatives. These are causative structures without subjects. The subject marking on the verb is sufficient hence no explicit one is required.

Consider;

light him look for caus

He needs light/ it made him look for light.

$$
\text { Farso -isa-haww-is-iis-a }
$$

local beer him wish for caus

he wishes for local beer/ it makes him look for local beer.

When a causative morpheme is added to a verb, the addition of a causer subject is obligatory. This is however not the case in (21 and 22). The caus -is- in barbaacc-is- (21) has not attracted any causer since ibsaa (light) is the patient while isa (him) is the cause. Likewise, in (22) neither farso (local beer) nor isa (him) is the causer subject in the sentence. In both, it is clear that the inner drive for something is the very cause to look for it. For instance, for clarity purposes, sentence (21) could be repetitively stated as 'The need for light made him look for light'

Causerless causatives are single causatives with only one causative morpheme. Mostly, subjectless causatives occur with verbs of desire such as haww (wish), ingestive verbs such as naacc (eat), emotion verbs such as aar (angry), cognitive verbs as irranfacc (forget) and motion verbs such as figg (run). Some verbs such as *bar-sis- (make know), though cognitive, are less acceptable in causer-less causatives because the verb 'make know' expresses activities in which the causee is actively and consciously involved in the action expressed by the verb as opposed to where the causee has a low level of involvement with the event.

As far as morphological causation is concerned,Shibatani(2000) notesthree criteria for linguistic expression of causation;

(i) Agent causing or forcing (causer) another participant (causee) to perform an action (event).

(ii) The relationship between the two events (causing and the caused event) and

(iii) The dependency of the events (causative making on the verb)

The three criteria apply perfectly in Gichuka for morphological causation too in the following ways:

(i) For every causative situation, there is always an additional causer argument

(ii) The relationship between the causing and the caused events is that of dependency.

(iii) With the morphological causation come a morphological marking on the verb

The details are shown in the analysis in Section 4.3.

According to (Anyanu) 2013, In lexical causatives, the causative-transitive verbs have no directed non-causative counterparts. Their causatives are considered causatives since they always contain a subject that causes someone or something to do or become something There are two types of lexical causatives according to Lyons (1968) namely; Labile and Suppletive.

In labile causation, the same verb enters into both causative and anti-causative alternations without any modifications of the verb itself. This means that there are two events expressed in a single lexical item as illustrated in (23a) for causative and (b) for anti-causative.

23 (a) John moved the stone (causative)

(b) The stone moved (anti-causative)

In Suppletive on the other hand, there is a lexical verb form which exists for causative and another one which exists semantically for non-causative. Different verb roots are used for causative-anti-causative alternations. Lyons, (1968) states that these are different pairs of verbs between which lies the same semantic and syntactic relationship, causativity, and that this relationship exists in both transitive and intransitive sentences. Consider the sentence (24); 
The rat died

(b)

$$
\text { A dog killed a rat }
$$

In (23) the same verb (move) enters into sentences of both causative (a) and anti-causative (b) while (24) is a pair of different verbs (kill/die) between which there is the same syntactic and semantic relationship, such that kill is the suppletive lexical causative while die is the suppletive lexical anti-causative. A few Bantu languages and English participate in lexical causation and I show in this study that Gichuka is rich in these pairs in both labile and suppletive.

In analytic type of causation, there is a lexical verb that functions as a causative marker in the language. Thecausing and thecaused events are encoded in separate clauses, meaning that analytic/syntactic causation is multi-clausal, with the matrix clause containing the causer event and the embedded clause containing the caused and the causing events. This causation has the structure Y causes X to verb. English has this verb as 'make' while Kiitharaka has it as 'tem-a' as shown in the examples (25) and (26) respectively. The syntactic causation in Gichuka is similar to the one in Kiitharaka with a slight difference in the vowel in the verb. The similarity is due to the relatedness of Gichuka and Kiitharaka. The Kiitharaka sentence (26) is due to Muriungi (2010).

$$
\begin{aligned}
& \text { John made Mary laugh } \\
& \text { John a-gu-tem-a Maria a-um-i-a nguo } \\
& \text { John sa-tns-made-fv Maria-sa-dry-ic-fv clothes } \\
& \text { John has made Maria to dry clothes. }
\end{aligned}
$$

An analytic causative construction has the following characteristics as discussed by Song (1996).

i. The causer noun and the predicate of cause must be foreground with the causee noun phrase and the predicate of effect. This is achieved by placing the clause expressing the causing event before the clause expressing the caused event.

ii. The predicate of cause and the predicate of effect are in different clauses.

iii. The expression of the causer's action should be without specific meaning. We consider example (27) for Kinyarwanda (Kimenyi, 1980) and (28) for Kithaaraka (Muriungi, 2010) respectively to check out for these properties and see whether Gichuka compares with them

$$
\text { Umuukobway-a-n-a amabaruwameensi }
$$

Girl -tum- me andik letters many

The girl caused me to write many letters

In the Kinyarwanda sentence (27) the causer noun phrase (umukoobwa) comes before the causee noun phrase (me). All that is expressed by the predicate of cause (tum) lacks specific meaning in that it expresses pure notion of causation while what is expressed by the predicate of effect (andik) has specific meaning (Kimenyi, 1980).

Kithaaraka also agrees with this as shown in (28) (Muriungi, 2010).

$$
\begin{aligned}
& \text { John -n-a-tem-ir-e- Maria -a-um-i-a- nguo } \\
& \text { John -f-sa-caus-pfv-fv- Maria sa- dry -caus-fv- clothes } \\
& \text { 'John made Maria to dry clothes' }
\end{aligned}
$$

All what is expressed by the predicate of cause $n$-a-tem-ir-e is not as specific as what is expressed by the predicate of effect $a-u m-i-a$.

Although both Kinyarwanda and Kiitharaka have both analytic and morphological strategies of causation as -ish- and -ith-respectively, the examples in (27 and 28) only focus on the analytic strategy of the two languages as tum and TEM-A to make clear their properties, after all a language can have a combination of causative strategies.

Besides Comrie's categorization (Morphological, Lexical and Syntactic), (Good, 2005) also notes root final consonant mutation whichhas also been noted to be associated with causation. Some Bantu languages derive causation through palatalised mutation of the root final consonant. For instance, in the Korekore dialect of Shona, the root final consonant mutation corresponds to palatalisation triggered by a transitive suffix immediately following the verb root. This is observed mostly with verbs ending in k,l,nd,t,mb,p and ng(Good, 2005).

svik- arrive

svits- make arrive 


\section{Theoretical Framework}

The study was guided by the X-Bar theory proposed by Noam Chomsky (1970) and developed by Jay Rackendoff (1977). Its purpose was to eliminate the need for special rules dictating that a noun phrase will always be dominated by a noun and a verb phrase by a verb. This is because there are other categories of phrases that are not headed by the traditional lexical items like nouns, verbs and adjectives among others. The theory captures the properties of phrases in all natural languages by determining the structural relations within the perspective of more general principles. According to X-Bar syntax, phrasal categories share certain similarities, like specifiers, heads and complements. It therefore expresses the relationships and interactions between these categories. Figure 2 shows the X -Bar Schemar and its constituents with the assumption that all phrases conform to the same configuration.

$$
\text { XP Maximal Projection }
$$

Specifier $\quad \mathrm{X}$ (Modifiers (optional))

$$
\text { (H ead) } \mathrm{X} \text { Complement }
$$

Figure 2. X-Bar Schemar

$\mathrm{XP}$ - This is the phrase category

Specifier - under the highest node of any phrase (XP) is the specifier to the left. It is the phrase that is the daughter of XP and modifies everything to the right which will be generated under X. It is subject-like and occurs with the head.

$\mathrm{X}$ - It is the head, a word that is the core of the phrase.

Complement - It is the phrase that is the sister of the head $(\mathrm{X})$ and which the head requires inside its phrase.

The $\mathrm{X}$ level can be expanded further using bars $\left({ }^{\prime}\right)$ in a process called recursion, which is a process that allows elements to be found within others through embedding. This theory was prefferedfor this study with the assumption that phrases in all languages conform to the X Bar configuration. The X Bar offers a unified approach to all phrasal structures and simplifies the concept of syntactic categories and their nature.

A causative sentence is defined under X Bar theory as an Inflectional Phrase (IP) since the head (X) is the inflection (I) which is occupied by caus in our case. This is a more general category that is not headed by the traditional lexical items like the verbs and the nouns. It is on this (I) that the lower clause is embedded bringing about recursion. Causation is explained on the ground of movement as a syntactic operation, and the $\mathrm{X}$ bar theory shows how the cause is produced and manipulated at the various components of grammar until it becomes a vocabulary item (causative morpheme) for insertion. According to Baker's theory of Incorporation, the embedded V is moved to the matrix V through I. On adjoining the matrix $\mathrm{V}$, it leads to creation of a complex word and changes the government relations inside the clause bringing about new case assignment relationships. X Bar theory, therefore, determines and expresses these structural relations within the perspective of more general principles.

\section{Methodology}

The study utilized descriptive survey method,in which data was described in order to reveal the strategies used for causationGichuka. The study was carried out in Chuka Division, Tharaka-Nithi County. This area was chosen because this is mainly where Gichuka speaking population is found. The target population of this study was Gichuka L1 speakers. These are the native Gichuka speakers associated with it by birth whose competence is at a masterly level.The sample size comprized ten (10) Gichuka native speakers and whose competence is at masterly level. Ten respondents were preffered since being a native speaker of the language, the researcher only sought to confirm what she knows about causation in Gichuka. The respondents were selected purposively on individuals who would give target structures. The study used Structure Generated Tests (SGTs) geared towards eliciting the target structures. Unstructured oral interviews were also used. The responses were studied, analyzed andpresentedin words, phrases, clauses and sentences.

\section{Strategies of Causation in Gichuka}

In this study two causative morphemes -ith- and -i-were noted. However, causation is also realized through the use of the analytic TUM-A. It is analytic since it is analyzable into parts $\boldsymbol{T U} \boldsymbol{M}-\boldsymbol{A}$ hence not qualified to be termed as a third morpheme, since a morpheme is un-analyzable.In his study of the readings of the Kitharaka causative morpheme, Muriungi (2010) also notes an analytic way which he calls the analytic TEM-A. Apart from the morphological -ith-, $-\boldsymbol{i}$ and the analytic TUMA mentioned, there is also lexical causation in which verb roots are used to show causation or lack of it (Haspelmath, 2010). A verb like kua (die) means that the event happened without any causer, while its 
causative counterpart-urag- (kill) is another lexical verb altogether. The two are related in that while one is inchoative plain, the other one bears the causative semantics. The details of the individual causative morphemes and the strategies of causation are discussed below under the strategies of causation namely: morphological, analytic, lexical and causative-inchoative.

\subsection{Morphological}

The morphological strategy of causation entails the use of causative morphemes to derive causation. Gichuka has two causative morphemes, $-\boldsymbol{i t h}$ - and $-\boldsymbol{i}$-, a trend adopted from the Proto-Bantu. This is because Bantu languages are very conservative. To create a causative expression in Gichuka, the morpheme -i- or -ith-is attached to the main verb. In this strategy of causation, both the causing and the caused events are encoded in a single verbal complex via a morphological marking on the verb showing the nature of the affected arguments. The two morphemes couldoccur separately or co-occur.Consider the sentences below with the intransitive verbs rir-a (cry) (30) and nyar-a (dry) (31). In the presentation of data, sentences stated in Gichuka are first glossed word by word and then their English equivalents given. This is the pattern used in linguistics to enable linguists who are not native speakers of the language to understand the data easily.

(30a) Mwana a-ku-rir-a

$$
\text { Child sa-tns-cry-fv }
$$

'The child has cried'

Example (1a) contains no causer and the event (crying) is spontaneous. When $-\boldsymbol{i}$ - is added, the introduction of an external causer subject is obligatory as illustrated in (b)

(b) Kanana a-ku-rir-i-a mwana

\section{Kananasa-tns- cry -caus-fvmwana}

'Kanana has made the child cry'

The verbal complex "a-ku-rir-i-a" contains the causer subject represented by the subject agreement (sa), the caused event (cry) and the morphological causative marking $-i$ -

Consider another verb nyar(dry) which can take both agentive and natural cause subjects.

$$
\begin{aligned}
& \text { Irindari-ku- nyar -a } \\
& \text { Dress-sa-tns-dry-fv } \\
& \text { 'The dress has dried' }
\end{aligned}
$$

When the causative morpheme $-\boldsymbol{i}$ - is introduced, the introduction of the causer is necessary, and this causer can either be agentive as in $(2 b)$ or a natural cause as in $(2 c)$

(b) Makena a-ku- nyar -i-airinda

Makena sa-tns- dry -caus-fv-dress

'Makena has dried the dress'

(c)

Riuari-ku- nyar -i-airinda

Sun's heat-sa-tns- dry -cause-fv- dress

'The sun's heat has dried the dress.'

From the examples in (30b, 31b and 31c), the following observations can be made about -i- causation;

(i) An external subject called causer is added. This is why there is Kanana (30b), Makena (31b) and riua (31c) which were not there in (30a) and (31a) respectively.

(ii) Both verbs rir-a (cry) and nyar-a (dry) are intransitive but on causation, they take the objects mwana (child) and irinda (dress) respectively.

(iii) The NPs (mwana) in (30a) and (irinda) in (31a) were subjects before causation but become objects after causation.

It is therefore, appropriate to say that besides being a causative, $\boldsymbol{- i}$ - is also a transitivizer, making intransitive verbs take objects.

The behavior of -i- causative is not different from that of its counterpart -ith- in that both of them introduce a causer subject, transitivize intransitives (31) and di-transitivize transitive verbs. Consider example (32). 
(32a) Gatwiri a-ku- ob -a- nku

Gatwiri -sa-tns tie -fv- firewood

'Gatwiri has tied firewood'

(b) Kanana a-ku- ob -ith-i-a Gatwirinku

Kanana -sa-tns- tie -caus-ic-fv- Gatwiri firewood

'Kanana has causedGatwiri to tie firewood'

-Ith- embeds a clause together with all the arguments the verb introduces, and is suffixed after the verb root. There are four properties notable about morphological causation in Gichuka so far;

(i) -ithand-i- are bound morphemes which cannot stand on their own but rely on the main verb for causative semantics.

(ii) Both are cases of suffixation

(iii) Together with the main verb, they form a single word which can function as a verb group on its own.

(iv) While-i- is strictly an internal causer, -ith- is both an internal and synthetic causer.The distinction between internal and synthetic causation is explained in details in this section.

A stronger tendency further noted is for $-\boldsymbol{i}$ - to attach on intransives and -ith- to transitives. This does not disregard the fact that a few intransitive verbs use -ith-for causation. Verbs like nyar (dry) and $g w$ - $a$ (fall) which are agentive intransitives may use -ith- for causation. Table 4 shows causation of intransitives with -i-while Table 4 indicates causation of transitives with -ith-

Table 4.Causation of Intransitive Verbs

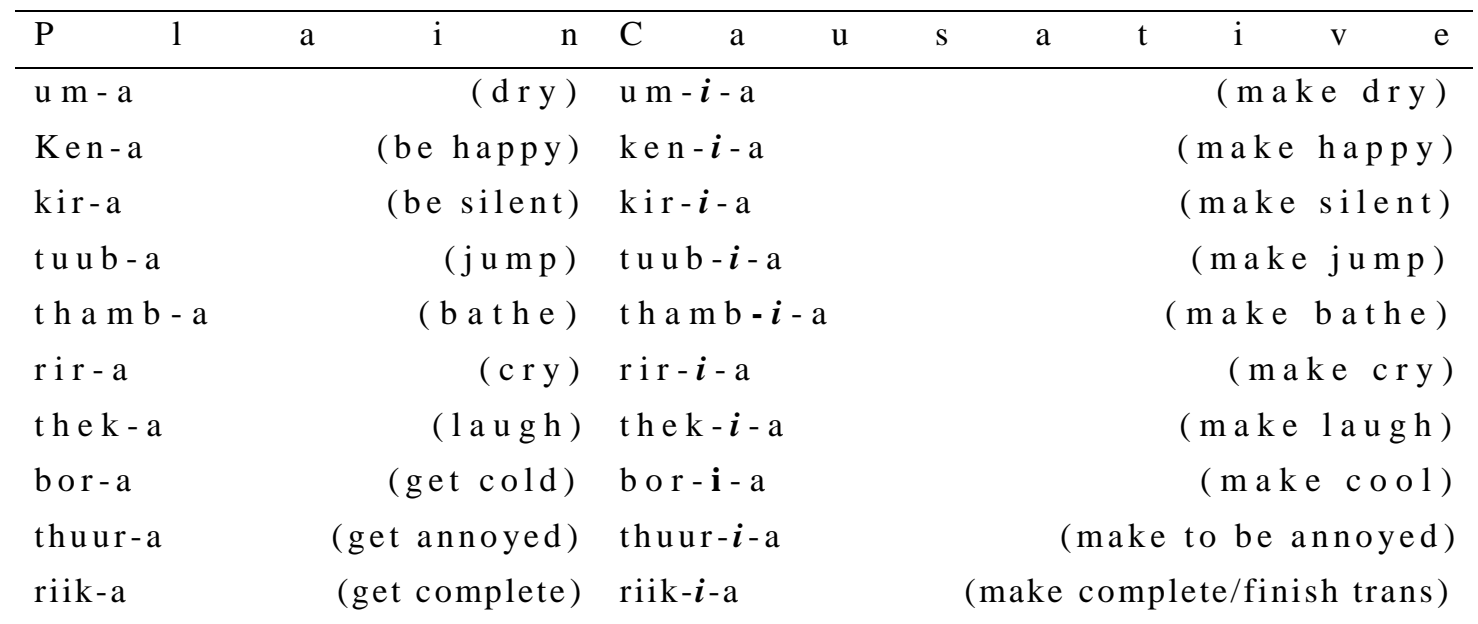

As can be noted from table 3, causation is realized with $-\boldsymbol{i}$ - only in intransitive verbs. Let us compare table 3 with table 4 that has causation of transitive verbs. 
Table 4. Causation of Transitive Verbs

\begin{tabular}{|c|c|c|c|c|c|c|c|c|c|c|}
\hline 1 & $\mathrm{a}$ & $\mathrm{n}$ & $\mathrm{C}$ & $\mathrm{u}$ & $\mathrm{s}$ & $\mathrm{a}$ & $\mathrm{t}$ & $\mathrm{i}$ & $\mathrm{V}$ & $\mathrm{e}$ \\
\hline $\mathrm{rug}-\mathrm{a}$ & & 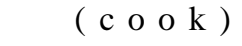 & \multicolumn{3}{|c|}{ rug-ith-i-a } & & \multicolumn{4}{|c|}{ (make to cook) } \\
\hline$o b-a$ & & $(\mathrm{t} i \mathrm{e})$ & \multicolumn{3}{|c|}{$\mathrm{ob}-\boldsymbol{i t h}-\boldsymbol{i}-\mathrm{a}$} & & \multicolumn{4}{|c|}{ (make to tie) } \\
\hline $\mathrm{t} a \mathrm{~b}-\mathrm{a}$ & & $(\mathrm{fet} c h)$ & \multicolumn{3}{|c|}{ tab-ith-i-a } & & \multicolumn{4}{|c|}{ (make to fetch) } \\
\hline $\mathrm{o} \mathrm{k} \mathrm{i} \mathrm{-} \mathrm{a}$ & & $(\mathrm{r} o \mathrm{a} s \mathrm{t})$ & \multicolumn{3}{|c|}{ ok-ith-i-a } & & \multicolumn{4}{|c|}{ (make to roast) } \\
\hline r i n $g-a$ & & $(\mathrm{~h} \mathrm{i} \mathrm{t})$ & \multicolumn{3}{|c|}{ ring $-i t h-i-a$} & & \multicolumn{4}{|c|}{ (make to hit) } \\
\hline $\mathrm{a} n \mathrm{~d}$ i k-a & & $(\mathrm{w} r \mathrm{i} t \mathrm{e})$ & \multicolumn{3}{|c|}{ andik-ith-i-a } & & \multicolumn{4}{|c|}{ (make to write) } \\
\hline k i n y - a & & $(\mathrm{s} \mathrm{t}$ e $\mathrm{p}$ o n $)$ & \multicolumn{3}{|c|}{ kiny-ith-i-a } & & \multicolumn{4}{|c|}{ (make to step on) } \\
\hline $\mathrm{t} e \mathrm{~m}-\mathrm{a}$ & & $(\mathrm{c} u \mathrm{t})$ & \multicolumn{3}{|c|}{ te m-ith-i-a } & & \multicolumn{4}{|c|}{$($ make to cut) } \\
\hline $\mathrm{n} y \mathrm{w}-\mathrm{a}$ & & $(\mathrm{d} r \mathrm{i} n \mathrm{k})$ & \multicolumn{3}{|c|}{ nyw-ith-i-a } & & \multicolumn{4}{|c|}{ (make to drink) } \\
\hline b a a $\mathrm{t}-\mathrm{a}$ & & $(\mathrm{s} w$ e e $p)$ & \multicolumn{3}{|c|}{ baat-ith-i-a } & & \multicolumn{4}{|c|}{ (make to sweep) } \\
\hline
\end{tabular}

When causation occurs in transitive verbs, $-\boldsymbol{i t h}$ - is used and occurs in the company of $\boldsymbol{i}$ - as can be seen in table 6 . When they are used together, -ith- is used for causation while $-\boldsymbol{i}$ - is used for transitivity. This is also attested in Muriungi (2008).

\subsection{Analytic TUM-A}

Causatives with analytic TUM-A are bi-clausal, with the matrix clause containing the causer argument and the embedded clause containing the causing event (Muriungi, 2010). TUM-A is the English equivalent of 'make' which embeds a clause at its complement. Unlike -ith-both agentive and natural causee subjects are possible and grammatical under TUM-A as illustrated in (33) for agentive and (34) for natural causee.

Kanana a-gu-tum-a-Gatwiri a-nyar-i-a- irinda

Kananasa-tns- make -fv- Gatwiri -sa- dry -ic -fv- dress

'Kanana has made Gatwiri dry the dress.'

Kanana a-gu-tum-a- riuari-a-nyar- $\boldsymbol{i}$-a- irinda

Kanana -sa-tns-make -fv-sun's heat -sa-tns- dry -ic -fv- dress

'Kanana has made the sun's heat to dry the dress.'

The Gichuka sentences with an analytic TUM-A also conform to the above assertions. Consider sentence (35);

$$
\text { Kanana -a-gu-tum-a Gatwiri -a-nyar-i-a irinda }
$$

Kanana -sa-tns- caus-fv- Gatwiri -sa- dry ic-fv- dress

Kanana made Gatwiri to dry the dress.'

The causer noun Kanana and the predicate of cause a-gu-tum- $a$ are foreground with the causee noun phrase Gatwiri and the predicate of effect $a$-nyar-i-a irinda. The predicate of cause $a$-gu-tum- $a$ and the predicate of effect $a$-nyar-i-a are in different clauses, the predicate of cause is in the matrix clause while the predicate of effect is in the embedded clause. The expression of the causer's action TUMA lacks in any specific meaning and expresses the pure notion of causation while the causee's action a-nyar-i-a has a specific meaning, to dry. The details of the clauses and their structure have been discussed in details in this section.

\subsection{Lexical}

In lexical causation, different verb roots are used for plain-causative alternations. According to Lyons (1968) as cited in Anyanu (2013), there is no formal relationship between the basic and its causative counterpart. It is also referred to as suppletive causation. Although not discussed in Kiitharaka (Muriungi, 2008 and 2010) which is genetically related to Gichuka, Gichuka is rich in these pairs. The difference between the pairs is that the causative member has one more argument and bears causative semantics. For instance the English pair die and kill is suppletive in that die is the basic verb without valence while kill is its causative counterpart. The two are completely different verbs without any similarity whatsoever. However, they are related in that while die is basic, kill is its causative counterpart and bears causative reading with an additional argument. Table 5 shows some of these pairs. 
Table 5. Gichuka Lexical Causative Verbs

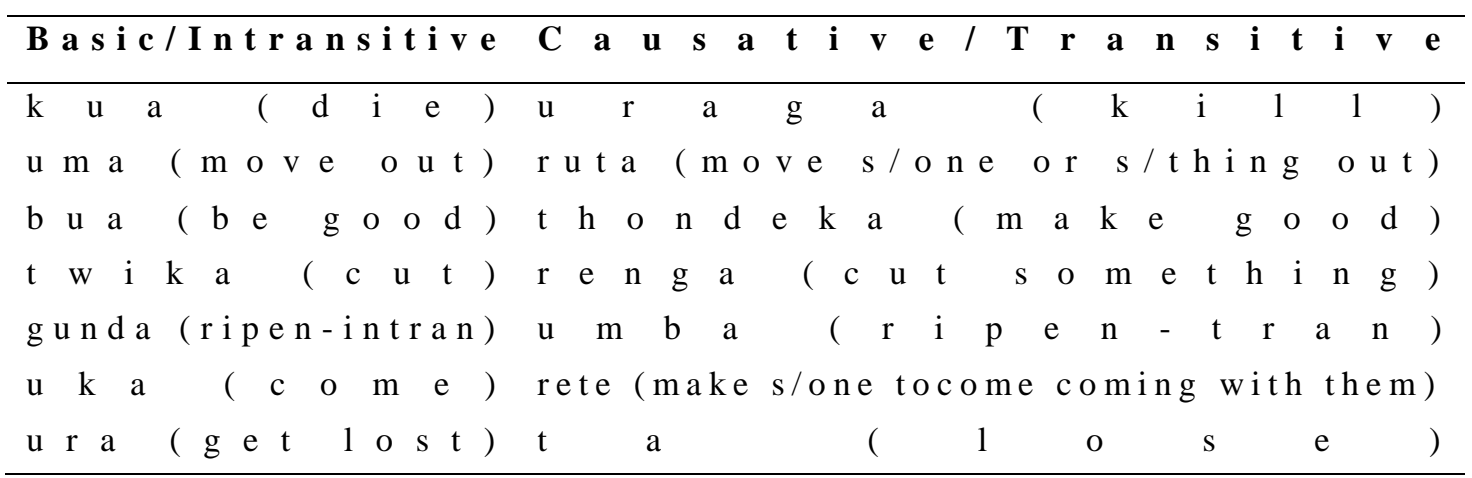

\subsection{Causative-Inchoative Alternation}

Causative-inchoative alternations are pairs of verbs, one transitiveand the other intransitive typically denoting a change of state (Haspelmath, 1993). Causative-Inchoative alternation means that only transitive causative verbs denoting events which may come about spontaneously without the intervention of an external willful animate causer may occur in the anti-causative alternation. There are three possibilities in this alternation and which are neither discussed in Muriungi (2008 or 2010). This study, therefore, contributes new data on causative patterns.

(i) The inchoative is basic and the transitive is derived such that the causative (caus) embeds the inchoative. In this case, the causee embeds the inchoative 'to become.' In some cases, a simplex verbal inchoative has a transitive alternant with an affixal causative alternant. An example of such a case includes the verb 'uma (dry) which is an inchoative simplex as compared to its causative complex umia (dry). However in most cases in this pattern, the causative embeds the state (become) through lability in which the same verb enters both causative and inchoative events. English has also these alternations for instance shrink (inchoative) and shrink (transitive), melt (inchoative) and melt (transitive) and clear (inchoative) and clear (transitive) among others. Both alternants are the same phonologically.Table 6 shows some of the verbs in Gichuka that portray this pattern.

Table 6. Causation/Labilility (Pattern i)

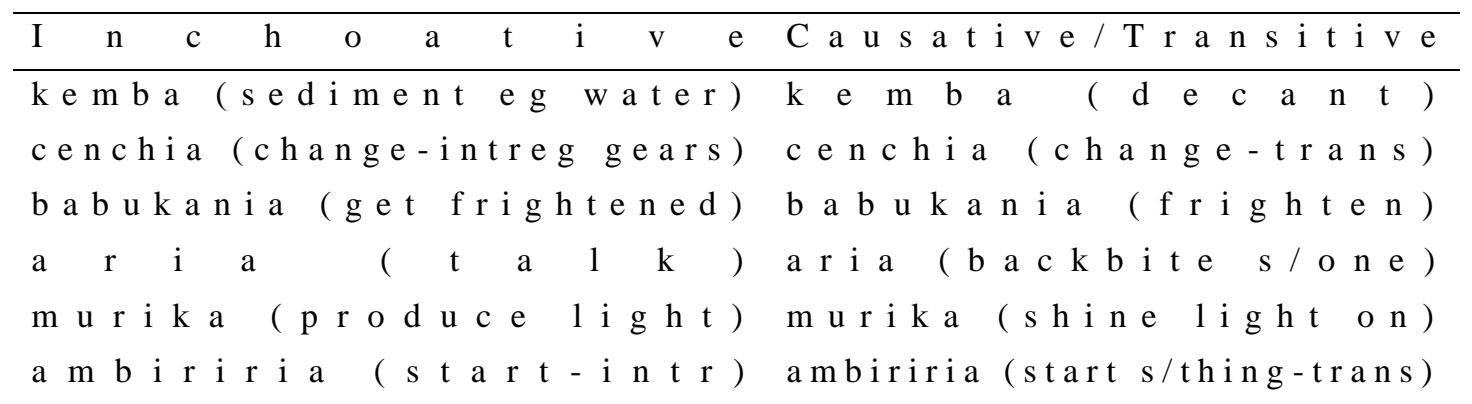

(ii) The transitive is basic and the inchoative is derived. The derivation of the inchoative alternant is a case of decaustivization where the causative undergoes an argument reducing operation.In Italian, it is indicated by the reflexive -si-for instance romper (break-transitive)andrompersi (break-intranstive) (Greg, 2012). The evidence for this pattern is that the unaccusative alternant differs from the causative in that it is more complex by having a reflexive morphology, an indication that the inchoative is derived. Table 7 shows some verbs in this pattern. 
Table 7. Decausativization (Pattern ii)

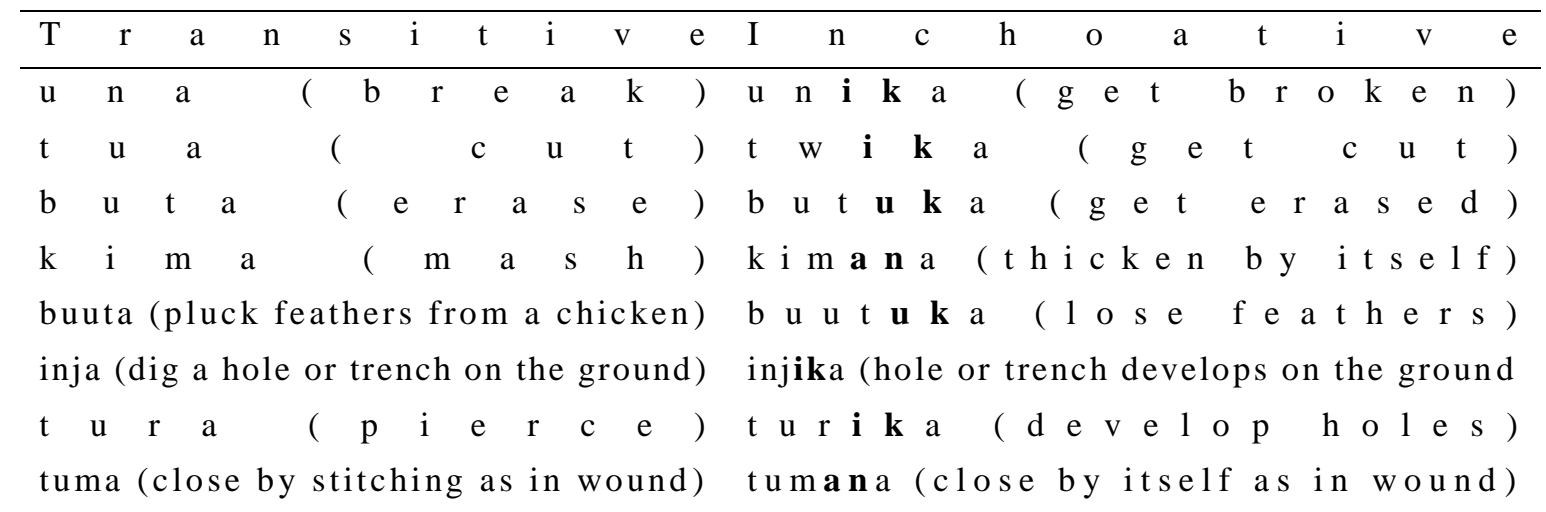

In Gichuka, the reflexive morphology can be indicated by $-u k-$, $-i k$ - or -an- on the verbs that portray pattern (ii) as shown on table 4. -an- here of reflexive should however, not be confused for -an- used for reciprocals. For instance, kim-an-a (thicken) and tum-an-a (get closed) as in table 4 cannever mean mash each other or stitch each other respectively. (iii) Neither is derived from the other but both. This pattern shows independent derivation where the morphemes deriving the alternants independently attach to a common base as shown in table 8 .

Table 8. Indipendent Derivation (Pattern iii)

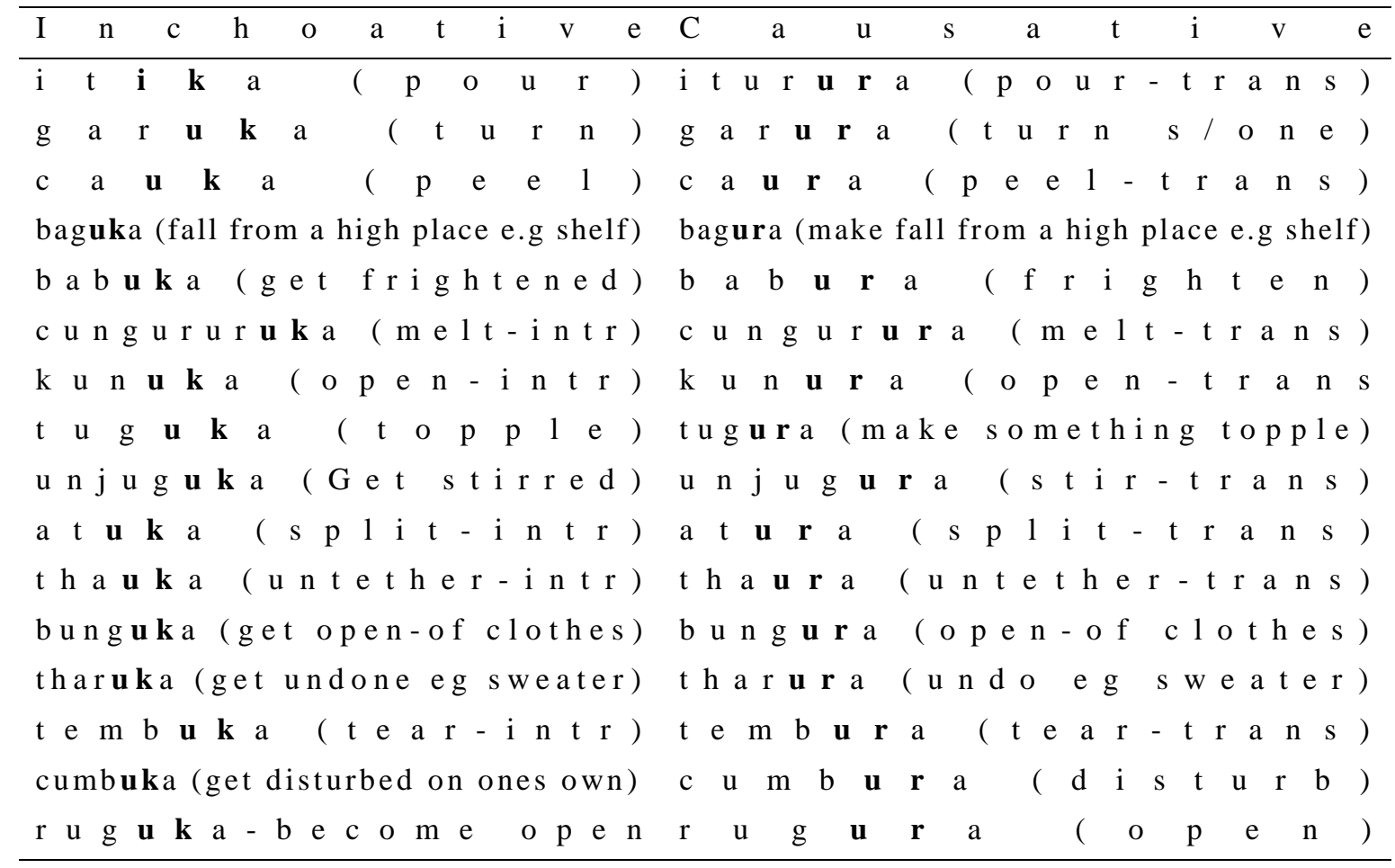

In Gichuka, the morpheme deriving the inchoative is -uk- or ik such that verbs with them are at their basic while the one deriving the causative alternant is -ur-.Both alternants have different morphologies attached on a common root. This shows that the derivations have been reached indipendently.

\section{Summary of Findings}

The purpose of this study was to investigate the strategies of causation in Gichuka. Gichuka has four strategies of causation; morphological, lexical, analytic and inchoative-causaivealternation.Morphologically, causation is realized by the use of the causative morphemes -i- and -ith-.In morphological causation, the causing and the caused events are encoded in a single verbal complex via a morphological marking showing the status of the affected arguments.Lexicaly, causation involves verb roots that exist for causation and others to show lack of it. There are two types of lexical causation namely; labile and suppletive. In labile, the same verb enters both causative and plain constructions, like 
kemba (clear), while suppletive involves two different verb roots, one existing for causative and the other for plain construction, for instance die and kill (kua/uraga). There is also analytic causation in which the analytic verb TUM-Aexists as a causative marker. It embeds a bare clause as its complement, making it a bi-clausal structure.

\section{Conclusion}

In view of the objectives, findings and analysis, this study concludes that Gichuka is a multi-strategy language as far as causation is concerned. Although chain causation is not realizable in Gichuka, double causation is only possible through combination of morphological and analytic TUM-A and not by doubling of the causative morpheme.

\section{References}

Alex, A. (1994). On the Argument Structure of Causatives.Linguistic Enquiry, 23, $517-555$.

Anyanu, O. (2013). Ibibio Causative and Anti-Caustive Verb Alternations. In Selected Proceedings of the $43^{\text {rd }}$ Annual Conference on African Linguistics, ed. Olanika Ola Orie and Karen W. Sanders, 106-114.

Baker, M. (1985).The Mirror Principle and the Morpho-syntactic Explanation.Linguistic Inquiry, 16, 373-415.

Baker, M. (1988).Incorporation: A Theory of Grammatical Function Changing: Chicago: University of Chicago.

Chomsky, N. (1970). Remarks on Nominalization.In Jacobs, R. and P.S. Rosenbaum (Ed).The Readings in English Transformational Grammar, 184-221.Waltham, Massachussetts. Gin and Co.

Chomsky, N. (1981). Lectures on Government and Binding.Dordecht: ForisPublication.

Chomsky, N. (1986). Knowledge of Language, Its nature, Origin and age. New York: Praeger.

Comrie, B. (1975). The Syntax of Causative Constructions: Cross-Languagesimilarities and divergencies (ed) Shibatani: The Grammar of causative constructions. New York: Academic Press.

Comrie, B. (1981). Language Universals and Linguistics Typology: Syntax andmorphology. Chicago: University of Chicago Press.

Culicover, P. (1976). Syntax. New York: Academic Press.

Culicover, P, and Jackendoff, R. (2005).Simpler Syntax. New York: OxfordUniversity Press.https://doi.org/10.1093/acprof:oso/9780199271092.001.0001

Odden, D. (2005). Introducing Phonology.UK: Cambridge University Press.https://doi.org/10.1017/CBO9780511808869

Dixon, R.M.W (2000). A Typology of Causatives: Form, Syntax and Meaning. (Ed) R.M.W. Dixon \& Alexandra, in Changing Valency. Cambridge: University Press.

Dixon, R. M. W. (1997). The Rise and Fall of Languages. Cambridge: CambridgeUniversity Press.https://doi.org/10.1017/CBO9780511612060

Fadiman, J. (1973). "Early History of theMeru of Mt. Kenya."Africa History (1993), 14, 1-27

Fadiman, J. (1976). The Pre-colonial Meru of Mt. Kenya. Ohio: Ohio University Centre for international studies.

Fasold, R. (1984). The Sociolinguists of Society. New York: Basil Blackwell.

Giraudo, H. \& Madeleine, V.R. (2007). Lexeme-Based Model vs Morpheme-BasedModel from Psycho-linguistic Perspectives in Selected Proceedings of the $5^{\text {th }}$ Decembrettes: Morphology in Toulouse, (eds) FabioMontermini, Gilles Boye and Nabil Hathaut108-114. Somerville, MACascadilla Proceedings Project

Good, J. (2003). Slouching towards Deponency: A Family of Mismatches in the Bantu Verb Stem.Max Planck Institute for Evolutionary Anthropology.

Good, J. (2005). Reconstructing Morpheme Order in Bantu: A Case of Causativization and Applicativization.Diachrronica, 22, 3-57.https://doi.org/10.1075/dia.22.1.02goo

Good, J. (2006). Constraining Morpho-Syntactic Templates: A Case Study of Bantu Verbal Suffixes. LSA Meeting, Albuquerque.

Goosken, C. (2007). The Contribution of Linguistic Factors to Intelligibility of Closely Related Languages.Journal of Multilingual and Multicultural Development, 28(6), 445.https://doi.org/10.2167/jmmd511.0

Greg, K. (2012). The Causative-Inchoative Alternation, And the Decomposition of the Little v. Coyote Papers 19(2012), University of Arizona. 
Guthrie, M. (1967).The Classification of Bantu Languages. London: Dawsons of Pall Mall.

Guthrie, M. (1967).Comparative Bantu.FarnBorough: Gregg Press.

Halle, M. \& Marantz, A. (1993).Distributed Morphology and the Pieces OfInflection. The View from Building, 20, 111-176.

Halle,M. (1997). Distributed Morphology: Impoverishment and Fission.MTWPL, 30, 425-449.

Hale, K. \& Keyser, S.J. (1993). On Argument Structure and Lexical Expression of Syntactic Relations.The View from Building, 20, Essays in linguistics in Honour of Sylvan Brombererger.

Hale, K. \& Keyser, S.J. (1992). The Syntactic Characteristic of Thematic Structure. In Thematic Structure: Its Role in Grammar, (ed) I.M. Roca.Berlin :Folis.https://doi.org/10.1515/9783110872613.107

Haspelmath, M.(1993). More on the Typology of Inchoative-Causative Verb Alternations: Bernard Comrie and Maria Polinsky (Eds.) Causativ and Transitivity, 88-120. Amstaderm: John Benjamins.https://doi.org/10.1075/slcs.23.05has

Haspelmath, M. (2008).Syntactic Universals and Usage frequencies.Leipzig Spring School on Linguistic Diversity.

Harley, H. \&Noyer, R. (1999). State of the Article: Distributed Morphology. GlotInternational, 4(4), 3-9.

Harley, H. (995). Sase Bizarre: The Structure of Japanese Causatives. In Proceeding of the Canadian Linguistic Society Meeting, ed. P Koskinen.

Hayman, L. (2007). Reconstructing the Proto-Bantu Verbal Unit: Internal Evidence.SOAS Working Papers, 15, 201-211.

Hayman, L. \&Mchombo, S.(1992). Morphotactic Constraints in the Chichewa Verb Stem.Proceeding of the Eighteenth Annual Meeting of the Berkeley Linguistic Society, General Session and Para-session.On the Place of Morphology in a Grammar.Berkeley Linguistic Society, 18, 350-364.https://doi.org/10.3765/bls.v18i1.1579

Hayman, L. (2003). Suffix Ordering in Bantu: A MorrphocentricApproach.G. Booijand J. Van Marle (Eds) Yearbook of Morphology. Dordrecht: Kluwer.

Jackendoff, R. (1977). X’Syntax: A Study of Phrase structure.CambridgeMassachussets: MIT Press.

Kathuri\& Pals, (1993).An Introduction to Educational Research.Njoro: Egerton University Educational Media Centre.

Kenya National Bureau of Statistics (2010).The National Housing Population Census.

Kimenyi, A. (1980). The Two Types of Causatives in Kinyarwanda: From Iconicity toSymbolicity. Retrieved November 22, 2014 from:www.kimenyi.com/causatives-in-kinyarwanda

Kothari, R. (2004). Research Methodology. New Delhi: New Age International Publishers.

Kratzer, A. (1984). On the Nature of Grammatical Relations.Cambridge: Mits Press.

Kroeger, G. (2004). Analysing Syntax: A Lexical-Functional Approach. Cambridge: Cambridge University Press.https://doi.org/10.1017/CBO9780511801693

Lambert, H. (1933).Chuka political record Book: An early history of Chuka-mwimbi. Nairobi: Nairobi National Archives.

Larson, K. (1988). On the Double Object Construction.Linguistic Enquiry, 19(3), 335-391.

Lehmann, C. (2005). Latin Causativization in Typological Perspctive.Presented at 13emeColloque International de linguistiqueLatine, Bruxelles, 4-8.

Lloret, M. R. (1987). The Morphology of Causatives in Oromo.Journal of African Languages and Linguistics, 9, 141-156. https://doi.org/10.1515/jall.1987.9.2.141

Lordhi, A. (2002). Verbal Extensions in Bantu.(The Case of Swahili and Nyamwezi).Africa and Asia,19(3), 4-26.

Lyons, B. (1968). Introduction to Theoretical Linguitics. Cambridge: CambridgeUniversity Press.https://doi.org/10.1017/CBO9781139165570

Maho, J. (2001). The Bantu Area: (towards Clearing up) a Mess. Africa and Asia, 1, 40-49.

Marantz, A. (1997). No Escape From Syntax: "Don't Try Morphological Analysis in the Privacy of Your Own Lexicon," University of Pennsylvania Working Papers in Linguistics, Philadephia Pennsylvania: Uppen Department of Linguistics. 
Marete, G.N. (1981). Grammatical Agreements in Kimeru: A transformational Approach.Dissertation.University of Nairobi.

Menn, L. and Brian, M. (1984). The Repeated Morph Constraint: Towards an Explanation. Language, 60, (3).https://doi.org/10.2307/413990

Mchombo, S. (2004).The Syntax of Chichewa. Cambridge: Cambridge University.https://doi.org/10.1017/CBO9780511486302

Mugenda, A. \&Mugenda, O. (1999).Research Methods: Quantitative and Qualitative Research Methods. Nairobi: Nairobi ACTS Press.

Muriungi, P. (2010). Accounting for the Readings of the Causative Morpheme in Kiitharaka.Nordic Journal of African Studies, 19(3), 180-199.

Muriungi, P. (2008). Phrasal Movement inside Bantu Languages.PhD Thesis.University of Tromso.

Mutegi, M. K. (2014). Strategies of Wh-Questions in Gichuka.Unpublished MA Thesis.ChukaUniversity

Mwangi, J. (1992).A Typology of Empty Categories in Kikuyu.Unpublished M A Thesis.University of Nairobi.

Mwaniki, H.S.K. (2005). Chuka Historical Texts. Indiana University: Media Document Supplies.

Mwaniki, H.S.K. (1974).Embu Historical Texts. Nairobi: East Africa Literature Bureau.

Ndwiga, S.M. (2008). A Syntactic Examination of Empty Categories in the Syntax of Gichuka: Government-Binding Perspective. Unpublished MA Thesis.University of Nairobi.

Ndwiga, S.M. (2014). Syntax and Pragmatics of the Gichuka Sentence: A Challenge to the Minimalist Program Analysis.Ph.D. Thesis.University of Nairobi.

Noyer, R. (1992).Distributed Morphology. Retrieved $\quad$ February $3, \quad 2013$ from:http//www.ling.upenn.edu/ rnoyer/dm\#too many functional headsprojections\#

Noyer, R. (1992).Distributed Morphology. Retrieved April 17, 2013 from: http//www.ling.upenn.edu/ rnoyer/dm\#spell-out\#

Nurse, D. (2003).The Bantu Languages. (eds) London. Routledge.

Orodho, J.A (2003). Elements of Education and Social Sciences Research Methods.Nairobi: Masola Publishers.

Oxford Advanced Learners Dictionary. $11^{\text {th }}$ Edition. (2006). Oxford: Oxford University Press.

Petur, M.G. (2012). The Development of Binary-Branching Theory in English Syntax in Relation to Double Complement Structures.Unpublished BA Essay.University of Iceland.

Radford, A. (1981). Transformational Syntax. Cambridge. Camridge University Press.

Robert, A. (2008). Role and Manifestation of Causative Morpheme 'Chi' in Cuzco, Quechua.MA Dissertation.The University of Pittsburgh.

Shibatani, M. (2001).The Grammar of Causation and Interpersonal Manipulation.Armsterdam: Benjamins.

Song, J.J. (1996). Causative and Causation: A Universal Typological Perspective. New York: Addison Wesley Longman.

Susanna, P. (2010). Complex Word Formation and the Morphology-Syntax Interface.Unpublished PhD Dissertation.University of Bercelona.

WaMberia, K. (1981). Consonants of Kitharaka.Unpublished MA Thesis.University of Nairobi.

WaMberia, K. (1993). Segmental Morphology with Special Reference to Noun and Verb.Unpublished PhD Dissertation.University of Nairobi. 